\title{
Pathogenicity of three entomopathogenic fungi, to the aphid species, Metopolophium dirhodum (Walker) (Hemiptera: Aphididae), and their Alkaline protease activities
}

\author{
Ouidad Abdelaziz ${ }^{1 *}$ (D) Mohamed Mourad Senoussi ${ }^{2}$, Amar Oufroukh $^{3}$, Ali Kemal Birgücü ${ }^{5}$, İsmail Karaca ${ }^{5}$, \\ Fayza Kouadri ${ }^{4}$, Benkenana Naima ${ }^{6}$ and Abderrahmane Bensegueni ${ }^{6}$
}

\begin{abstract}
The aim of the present study is to investigate the effect of three entomopathogenic fungi (EPF) (Beauveria bassiana, Cladosporium cladosporioides, and Verticillium alfalfae) on the aphid species, Metopolophium dirhodum (Walker) (Hemiptera: Aphididae). The selected EPF were isolated from the agricultural soil of the National Institute of Plant Protection (INPV) in Constantine, Algeria, and were tested against the aphid insects that were collected from the same area. The aphid species $M$. dirhodum were exposed to each fungal spore suspensions $10^{7}$ conidia/ml for $10 \mathrm{~s}$. Percent mortality was recorded at 1, 3, 5, and 7 days post treatment. Percentage mortalities, 7 days post treatment, were $95.83,63.98$, and $51.83 \%$ by B. bassiana, C. cladosporioides, and $V$. alfalfae, respectively. The higher protease activities were observed for isolate $V$. alfalfae with $95 \mathrm{U} / \mathrm{ml}$, followed by B. bassiana with $38.26 \mathrm{U} / \mathrm{ml}$, and finally $C$. cladosporioides with $35,65 \mathrm{U} / \mathrm{ml}$. The results presented in this study revealed that there was no relation between high alkaline protease activities and high virulence isolates.
\end{abstract}

Keywords: Entomopathogenic fungi, Metopolophium dirhodum, Mortality rate, Alkaline protease activity

\section{Background}

The aphids are the most harmful insects that affect wheat plants. Diuraphis noxia (Mordvilko), Sitobion avenea (F.), Schizaphis graminum (Rondani), Rhopalosiphum padi (L.), Metopolophium dirhodum (Walker), and Sipha maydis (Passerini) are the most inimical insect pests that depreciate substantially cereal cultures (Blackman and Eastop 2000).

$M$. dirhodum is the most important species that could destroy grains all over the world (Dixon 1987). It chooses its host during the cold season and then emigrates toward drought cereals in summer and is able to transmit a Luteovirus and provides a wide resistance against exterminators (Carter et al. 1980). The biocontrol methods, using entomopathoganic fungi (EPF), are among the most effective ones (Wells et al. 2000).

\footnotetext{
*Correspondence: az_wided@yahoo.fr; abdelaziz.wided@umc.edu.dz ${ }^{1}$ Université des frères Mentouri Constantine, Département de Microbiologie, Constantine, Algeria

Full list of author information is available at the end of the article
}

The efficiency of these fungi lies in the fact that they can fight against exterminators by invading insect crusts. They usually infect insects by active penetration through the cuticle and are able to control insects regarding their feeding environment.

The insect cuticle is the first barrier that fungi encounter. Accordingly, a wide variety of extracellular enzymes are synthesized for the enzymatic processes involved in the degradation of protein, chitin and lipids, which are the basic cuticle components (St. Leger et al. 1986). Different studies suggested that proteases and chitinases are major determinants of fungal virulence in the complex and multifactorial phenomenon insect host/ pathogen relationship (Fang et al. 2007).

Protease Pr1 was also found as a virulence indicator in EPF (Castellanos-Moguel et al. 2007). High pathogenicity on Heliothis armigera and cotton aphid has been observed by locally isolated EPF grown on Sabouraud dextrose medium by laboratory bioassay methods (Shahid et al. 2012). These experiments were designed 
to check similarities at the level of virulencedetermining factors. VCP1 (VCP1 as abbreviation means "Verticillium chlamydosporium") serine-like protease virulence factors, which are pathogenic toward both Heliothis and aphids, were grown in liquid medium at a large scale (Shahid et al. 2003).

The activities of protease have been determined in $M$. anisopliae var. anisopliae, B. bassiana, and Verticillium lecanii when grown on the cuticle of the locust Schistocerca gregaria (St. Leger et al. 1986).

Thereby, the main objective of the present study was to evaluate the most effective fungi against $M$. dirhodum and the production of an alkaline protease using Locust meal of Ocneridia voleximii (Pamphaginae, Orthoptera) as a basal substrate, which suggested to select the most widespread strains for biological control of aphids.

\section{Materials and methods}

Insects' rearing

Metopolophium dirhodum was collected from a wheat variety (Cirta HD.122) (Triticum eastivum L.). The aphid was cultured on wheat for several generations, before the commencement of the experiment, at the National Institute of Plant Protection' suburb (INPV) of Constantine-Algeria.

\section{Fungal isolates}

The virulence of three fungal isolates (Beauveria bassiana, Cladosporium cladosporioides, and Verticillium alfalfae) was tested. The fungi used in this study were isolated from an agricultural soil of the INPV. Isolation of EPF was determined according to the method described by (Vinayaga Moorthi et al. 2015), with minor modification. One gram (1 g) of the soil was diluted in $9 \mathrm{ml}$ of distilled water, and then, $100 \mu \mathrm{l}$ of the dilutions $\left(10^{-3}, 10^{-4}, 10^{-5}\right)$ was planted in Potatoes Dextrose Agar (PDA: 200 g potatoes, 20 g D. Glucose, and 20 g Agar), supplemented with Chloramphenicol (10 mg/1 L).The dishes were incubated for 2 weeks at $28{ }^{\circ} \mathrm{C}$. The macroscopic and microscopic of resultant fungal growths were compared in terms of taking into account the standard description of mycelium and spore (De Hoog 1972; Samson et al. 1988).

\section{Pathogenicity bioassay}

The aphids were immersed for $10 \mathrm{~s}$ in each fungal suspension, which was prepared at the concentration $\left(1.10^{7}\right.$ conidia $\left./ \mathrm{ml}\right)$ of sterile distilled water and supplemented with a drop of Tween 80 (0.05\%). Dishes were kept at room temperature of $25{ }^{\circ} \mathrm{C}$ and $60 \%$ R.H. The mortality rates of the aphids were evaluated on 1st, 3rd, 5th, and 7th day after inoculation. All the treatments were repeated six times. Obtained data were analyzed. Tukey test was applied after one-way ANOVA for numbers of live individuals, using SPSS $^{\circ}$ for data analysis (version 17.00 Software. 2006 SPSS.Inc.Chicago.il, USA). The percentage effects of the three fungal isolates were calculated and corrected by Abbott's (1925) formula:

$$
\begin{aligned}
& \text { Abbott s corrected mortality } \%= \\
& \frac{(\text { mortality in control-mortality in treatment) }}{\text { mortality in control }} \times 100
\end{aligned}
$$

\section{Enzymes' essays Screening for protease enzyme production}

The three EPF (B. bassiana, C. cladosporioides, and $V$. alfalfae) were tested for their ability to produce the protease enzyme. Caseins hydrolysis was added to $20 \%$ of agar and then $0.2 \%$ of skimmed milk (called Candia) was also added to the agar plates (Larsen et al. 1998). The plates were then incubated at $28{ }^{\circ} \mathrm{C}$ for 3 days. The enzyme activity was indicated by the formation of a clear zone around the colonies.

\section{Fungi and inoculum's preparation}

The tested fungal isolates were propagated on PDA medium in plates at $28{ }^{\circ} \mathrm{C}$. After 2 weeks, the plates were scraped with $10 \mathrm{ml}$ of sterile water that contained $0.05 \%$ Tween 80 . The spore suspension was adjusted to the desired concentration $\left(10^{7}\right.$ conidia $\left./ \mathrm{ml}\right)$ after counting with Malassez cell.

\section{Fermentation condition}

The culture medium used for production of alkaline protease was carried out by using Locust meal of Ocneridia voleximii (Pamphaginae: Orthoptera) which is considered as a basic substrate provided by the laboratory of biosystems and ecology of Arthropod at Mentouri Brothers University of Constantine, Algeria. Locust material was dried in shade at room temperature and then ground by using a blender. Two grams of powdered locust was soaked in $50 \mathrm{ml}$ of distilled water. A fungal suspension $(1 \mathrm{ml})$ containing $10^{7}$ of conidia $/ \mathrm{ml}$ was inoculated into Erlenmeyer flasks containing $50 \mathrm{ml}$ of culture medium with an adjusted $\mathrm{pH}(\mathrm{pH}=4.5)$. Flasks were kept at $28{ }^{\circ} \mathrm{C}$ under agitation at $120 \mathrm{~g}$ for 3 days. The mycelia mass was obtained by filtering the content of each flask and then drying it at $105^{\circ} \mathrm{C}$ until it reached a constant weight. The filtrate was used as a crude enzyme extract for the enzyme's assay. The experiment was triplicated, and the mean values were calculated.

\section{Alkaline protease activity}

Based on Mechakra et al. 1999 method, a proteolytic activity assay was done using casein as the substrate. The enzyme activity was determined by incubating $1 \mathrm{ml}$ of 
crude enzyme extract (EE) with $2.5 \mathrm{ml}$ of casein sodium citrate $(0.02 \mathrm{M})$ and $1.5 \mathrm{ml}$ of Tris- $\mathrm{HCl}(0.2 \mathrm{M} / 0.1 \mathrm{M})$ with $\mathrm{pH}=8$. The mixture was incubated for $30 \mathrm{~min}$ at $40{ }^{\circ} \mathrm{C}$, and the reaction was stopped by adding $5 \mathrm{ml}$ of Trichloro-acetic (TCA). Thereafter, it left for $30 \mathrm{~min}$ in ice. The precipitated casein was then filtered off. $0.5 \mathrm{ml}$ of the filtrate was taken in a test tube with $2.5 \mathrm{ml}$ of $\mathrm{NaCO} 3$ in $2 \% \mathrm{NaOH}(0.1 \mathrm{~N})$, and then, $0.25 \mathrm{ml}$ of the follin Ciocalten reagent $(1 \mathrm{ml}$ diluted with $3-\mathrm{ml}$ distilled water) was added. A proteolytic activity was determined by the absorbance reading at $750 \mathrm{~nm}$. Blanks of the samples were prepared by adding the TCA before the addition of substrate. Tyrosine was used as standard. One unit of protease activity was defined as the amount of enzyme that produced $1 \mathrm{mM}$ of Tyrosine per minute above conditions. Tyrosine was taken as the standard for all the enzyme assay calculations.

\section{Results and discussion}

\section{Pathogenicity bioassay}

As illustrated in Fig. 1, 7 days post treatment, the rate of mortality of $M$. dirhodum varied relatively between 52 and $96 \%$. The results revealed that B. bassiana had the most effective toxicity (95.83\%), followed by $C$. cladosporioides (63.98\%) and then $V$. alfalfae (51.83\%).

The scale values of the population density of $M$. dirhodum are given in Table 1. Aphid population densities at the treatments with the fungal isolates were compared with control at $1,3,5$, and 7 days post treatment. Before treatment, the population densities were not significantly different at any treatment. The lowest population densities (1.00 and 0.017 individuals) were recorded on B. bassiana at 5 and 7 days post treatment, respectively, while the highest ones (2.67 and 1.67 individuals) were observed on $V$. alfalfae on the same dates. The respective population densities on C. cladosporioides were (2.33 and 1.33 individuals) at 5 and 7 days post treatment.

All isolates produced different mortality values among treatment; the highest mortality value was obtained on 7 days post treatment $\left(F_{7 \mathrm{DAA}}=32.698, \mathrm{df}=3, p \leq 0.00\right)$.
The results' statistics in 3rd and 5th were significant $\left[\left(F_{3 \mathrm{DAA}}=8.333, \mathrm{df}=3, p \leq 0.001\right) ;\left(\mathrm{F}_{5 \mathrm{DAA}}=14.556, \mathrm{df}=3\right.\right.$, $p \leq 0.00)]$.

More than 750 fungal species were reported as potent agents against insect propagation (Gillespie et al. 1998). Saranya et al. (2010) stated that C. cladosporioides caused $77.50 \%$ mortality in Aphis craccivora (Koch) at a concentration of $10^{8}$ conidia/ml. B. bassiana killed $96 \%$ of the aphids within 7 days after application. These results corroborate those of Murerwa et al. (2014) who reported that $B$. bassiana developed a considerable activity against $M$. dirhodum, and the mean mortalities ranged from 84 to $90 \% 10$ days after application. Bensaci et al. (2015) revealed that the maximal mortality rate of C. oxysporum against Aphis fabae was $67.90 \%$ at the concentration of $10^{8}$ conidia $/ \mathrm{m}$.

On the contrary, Abdel-Baky and Abdel-Salam 2003showed that the maximal mortality rates of Cladosporium spp. on Aphis gossypii and Aphis craccivora were 37.5 and $38 \%$, respectively, 3 days after application with a concentration of $10^{6}$ conidia $/ \mathrm{ml}$.

In the present study, the results that describe the effect of $V$. alfalfae on aphids were approximately similar to those reported by Chavan et al. (2008). Their results showed that the efficacy of $V$. locanii was high in a sense that they had an immense mortality rate ranged between 68.23 and $89.54 \%$ on aphids.

\section{Alkaline protease activity}

The screening of fungi in order to determine their protease activity was carried out by hydrolysis on Agar plates that contain $0.2 \%$ Skim milk in $20 \%$ agar. After incubation at $28{ }^{\circ} \mathrm{C}$ for 7 days, the enzyme activities were detected by the appearance of a zone around the fungal colonies. $V$. alfalfae showed the highest zone around the colony with $\phi=5.1 \mathrm{~cm}$, followed by $C$. cladosporioides with $\phi=2 \mathrm{~cm}$, and then $B$. bassiana with $\phi=1.3 \mathrm{~cm}$ (Fig. 2).

Alkaline protease activity in the culture of locust meal of $O$. volexemii was detected at $28{ }^{\circ} \mathrm{C}$ for 3 days. The higher protease activities were observed for $V$. alfalfae

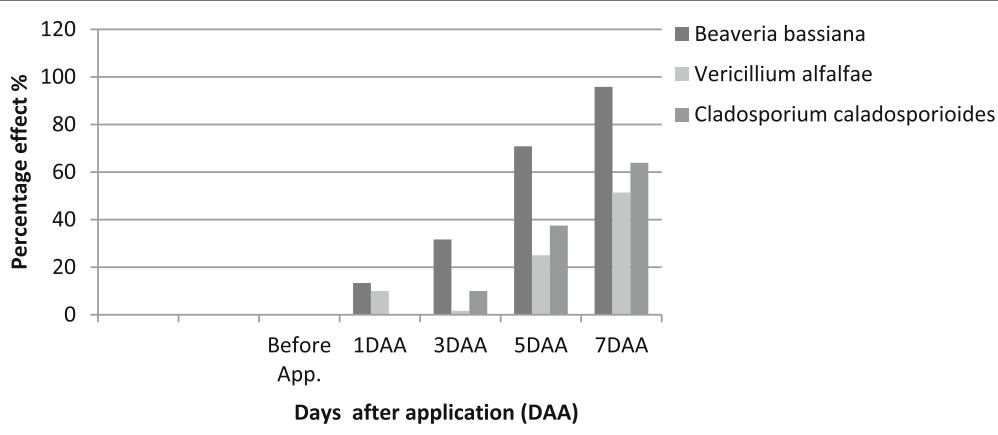

Fig. 1 Percentage mortality of three fungi on Metopolophium dirhodum 
Table 1 The scale values of the population density of Metopolophium dirhodum

\begin{tabular}{|c|c|c|c|c|c|}
\hline \multirow[t]{2}{*}{ Fungal isolates } & \multirow[b]{2}{*}{ Pre-tre atment } & \multicolumn{4}{|c|}{ Days post treatment } \\
\hline & & $\overline{1 s t}$ & $3 r d$ & 5th & 7th \\
\hline Beauveria bassiana & $5.00 \pm 0.00^{\mathrm{a}}$ & $4.33 \pm 0.21^{b}$ & $3.17 \pm 0.17^{c}$ & $1.00 \pm 0.37^{c}$ & $0.017 \pm 0.17^{d}$ \\
\hline Cladosporium cladosporioides & $5.00 \pm 0.00^{\mathrm{a}}$ & $5.00 \pm 0.00^{b}$ & $4.17 \pm 0.17^{\mathrm{abc}}$ & $2.33 \pm 0.33^{b}$ & $1.33 \pm 0.33^{c}$ \\
\hline Verticillium alfalfae & $5.00 \pm 0.00^{\mathrm{a}}$ & $4.5 \pm 0.22^{b}$ & $4.5 \pm 0.34^{\mathrm{ab}}$ & $2.67 \pm 0.21^{a b}$ & $1.67 \pm 0.21^{b c}$ \\
\hline Control & $5.00 \pm 0.00^{\mathrm{a}}$ & $5.00 \pm 0.00^{\mathrm{a}}$ & $4.67 \pm 0.21^{\mathrm{a}}$ & $3.67 \pm 0.21^{\mathrm{a}}$ & $3.50 \pm 0.22^{\mathrm{a}}$ \\
\hline$P$ value & NS & 0.000 & 0.000 & 0.000 & 0.000 \\
\hline S.E.M & 0.00 & 0.062 & 0.23 & 0.21 & 0.26 \\
\hline
\end{tabular}

$\overline{a, b, c,}$, means, with different superscripts within a same line, are significantly different according to Tukey's HSD multiple range test $(P<0.05)$. $P$ probability, S.E.M standard error mean. NS not significant

with $95 \mathrm{U} / \mathrm{ml}$, followed by B. bassiana with $38.26 \mathrm{U} / \mathrm{ml}$, and then C. cladosporioides with $35,65 \mathrm{U} / \mathrm{ml}$.

The $\mathrm{pH}$ of the medium showed a large change in the case of isolates $V$. alfalfae (7.89), B. bassiana and $C$. cladosporioides (6.92) knowing that the initial $\mathrm{pH}$ was adjusted to 4.5 .

This increase is explained by the release of alkaline molecules such as the ammonia that results from the degradation of proteins and leads to the decreases of the production of organic acids. This indicates also that the strains had certainly used the locust meal of O. vloximii, differently, and as the only source of carbon in the protein production. In effect, the variations of $\mathrm{pH}$ are considered as indicators of change in the metabolic process, including enzymes (Sandhya et al. 2005).

Extracellular proteases were even found in the insect haemolymph (Shimizuy et al. 1993). An immense variation in the protease activity was observed among the B. bassiana, C. cladosporioides, and $V$. alfalfae. A level of protease was observed in $V$. lecanii, and the highest levels were produced, solely, in cuticle substrate. Insect cuticle stimulated the protease production by both $V$. locanii and $V$. alboatum and with the adaptation of Verticillium spp. The protease production occurred in the insect cuticle that does not require substantial changes in the regulatory conditions of protease expression genes. These results are similar to those reported by (Barranco-Florido et al. 2002) when the proteolytic was lower submerged fermentation (cuticule of Sphenarium purpurascens, $20 \mathrm{~g} / \mathrm{l} ;\left(\mathrm{NH}_{4}\right)_{2} \quad \mathrm{SO}_{4}, 3 \mathrm{~g} / \mathrm{l} ; \mathrm{MgSO}_{4}$, $\left.0.6 \mathrm{~g} / \mathrm{l} ; \mathrm{NaCl}, 0.5 \mathrm{~g} / \mathrm{l} ; \mathrm{KH}_{2} \mathrm{PO}_{4}, 10 \mathrm{~g} / \mathrm{l}\right)$. They were 66.35 and $92 \%$ lower for proteolytic in the strains $V$. lecanii ATCC26854, ATCC 46578 and wild strain (WS).

In the present study, the protease activity by $B$. bassiana $(38.26 \mathrm{U} / \mathrm{ml})$ was approximately similar to those reported by Ito et al. (2007), demonstrating high protease activity on the 5th day of culture in B. bassiana. The time for maximum protease production does not necessarily depend upon the media constituents. Kucera (1971) observed high amounts of protease release 3 days after inoculation with different nitrogen sources. Proteolytic activity of $B$. bassiana is influenced by the culture age. This is probably due to the nutrient limitation or the autolysis of the culture (Braga et al. 1999).

Fungal pathogenesis of insect is related to many different factors such as hosting, parasitizing, and the environment as well. In the initial contact between fungus and insect, after the adhesion process, the penetration of the fungal pathogen into cuticle depends relevantly on the action of the enzymatic activities (St. Leger et al. 1987).

Jakovljević (2016) found that the alkaline protease activities of C. cladosporioides were enhanced by the addition of pollutant for $56.88 \%$ in in Czapek-Dox liquid nutrient medium with the addition of $0.5 \%$.

\section{Conclusion}

Under the present experimental conditions, the results revealed that there was no relationship between a high alkaline protease activity and high virulence isolates. $B$. bassiana had the most effective toxicity (95.83\%) but the high alkaline protease activity was observed in $V$. alfalfae $(95 \mathrm{U} / \mathrm{ml})$. Many factors influence directly and

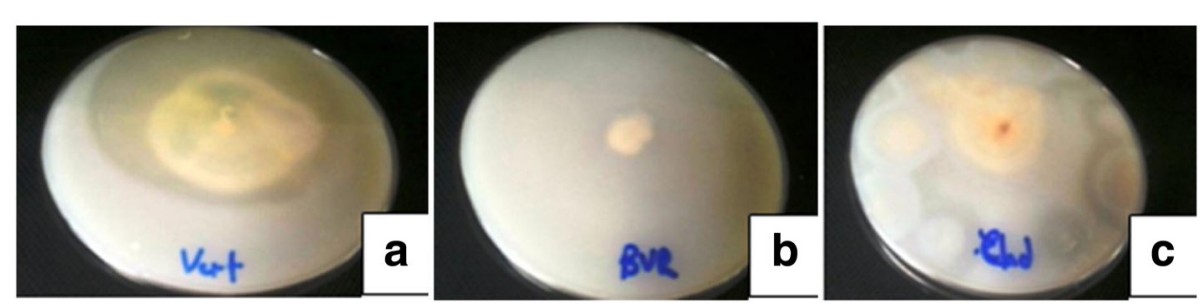

Fig. 2 Screening of fungi protease enzyme production, a Verticillium alfalfae, b Beauveria bassiana, c Cladosporium cladosporioides 
indirectly protease activity and the virulence isolates in this process. More research is needed about this complex mechanism.

Obtained results showed that the fungal isolates used might be utilized as biocontrol agents against the aphids. Among them, B. bassiana was the most promising one. Further studies should include evaluating the efficacy of the isolate in the field. However, this present work indicated the potentiality of $V$. alfalfae as a new resource of alkaline protease, which may suggest that protease activities could be used in the selection of candidates for aphids biological control.

\section{Acknowledgements}

The authors thank Süleyman Demirel Üniversitesi, Ziraat Fakültesi, Bitki Koruma Bölümü, 32260, Isparta-Türkiye, Mentouri Brothers Constantine, Faculty of SNV, Constantine, Algeria, and the National Institute of Agronomic Research Constantine-Algeria (INRA. Constantine), for their kind and great help.

\section{Authors' contributions}

$\mathrm{OA}, \mathrm{MMS}$ and $\mathrm{AO}$ collaborated in the creation of the manuscript. ALB and participated in the pathogenicity test. In addition to that, $\mathrm{OA}, \mathrm{MM}, \mathrm{AO}, \mathrm{FK}$ and $A B$ elaborated in the identification of the fungi and enzyme's test. Finally, BN is the one that produced locusts ( Ocniridia voleximii ). All authors read and approved the final manuscript.

\section{Competing interests}

The authors declare that they have no competing interests.

\section{Publisher's Note}

Springer Nature remains neutral with regard to jurisdictional claims in published maps and institutional affiliations.

\section{Author details}

'Université des frères Mentouri Constantine, Département de Microbiologie, Constantine, Algeria. ${ }^{2}$ Université Larbi Ben M'hidi Oum Elbouaghi, Département de SNV, Oum Elbouaghi, Algeria. ${ }^{3}$ Institut National de la Recherche Agronomique (INRA), Constantine, Algeria. 'Biology Department, Faculty of Science, Taibah University, Saudi Arabia, Saudi Arabia. ${ }^{5}$ Süleyman Demirel Üniversitesi, Ziraat Fakültesi, Bitki Koruma Bölümü, 32260 Isparta, Türkiye. ${ }^{6}$ Université des frères Mentouri Constantine, Département de Biologie Animal, Constantine, Algeria.

Received: 2 October 2017 Accepted: 15 January 2018

Published online: 08 March 2018

\section{References}

Abbott WS (1925) A method of computing the effectiveness of an insecticide. J Econ Entomol 18:265-267

Abdel-Baky NF, Abdel-Salam AH (2003) Natural incidence of Cladosporium spp. as a bio-control agent against whiteflies and aphids in Egypt. J Appl Entomol 127(4):228-235

Barranco-Florido JE, Alatorre-Rosas R, Gutiérrez-Rojas M, Viniegra-González G, Saucedo-Castaňeda G (2002) Criteria for the selection of strains of entomopathogenic fungi Verticillium lecanii for solid state cultivation. Enzym Microb Technol 30:910-915

Bensaci OA, Daoud H, Lombarkia N, Rouabah K (2015) Formulation of the endophytic fungus Cladosporium oxysporum Berk. \& M.A. Curtis, isolated from Euphorbia bupleuroides subsp. luteola, as a new biocontrol tool against the black bean aphid (Aphis fabae Scop.) J T Plant Prot Res 55(1):2015

Blackman RL, Eastop VF (2000) Aphids on the world's crops: an identification and information guide. Wiley, Chichester, p 476

Braga GUL, Destefano RHR, Messias CL (1999) Protease production during growth and autolysis of submerged Metarhizium anisopliae cultures. Rev Microbiol 30:107-113

Carter N, McLean IFG, Watt AD, Dixon AFG (1980) Cereal aphids: a case study and review. In: Coaker TH (ed) Applied biology. Acad. Press, London, pp 271-348
Castellanos-Moguel J, Gonzalez-Barajas M, Mier T, Reyes Montes MR, Aranda E, Toriello C (2007) Virulence testing and extracellular subtilisin-like (Pr1) and tripsina-like (Pr2) activity during propagule production of Paecilomyces fumosoroseus isolates from whiteflies (Homoptera: Aeyrodidae). Rev Iberoam Micol 24:62-68

Chavan BP, Kadam JR, Saindane YS (2008) Bioefficacy of liquid formulation of Verticillium lecanii against aphid (Aphis gossypii). Int J Plant Prot 1(2):69-72

De Hoog GS (1972) The genera Beauveria, Isaria, Tritirachium and Acrodontium. Gen Nov Stud Mycol 1:1-41

Dixon AFG (1987) Cereal aphids as an applied problem. Agric Zool Rev 2(1):1-57 Fang WG, Gou SJ, Pei XQ, Zhang YJ, Xiao YH, Li DM, Jin K, Bidochka MJ, Pei Y (2007) Increased insect virulence in Beauveria bassiana strains overexpressing an engineered chitinase. Appl Environ Microbiol 73:295-302

Gillespie J, Bateman PR, Charnley AK (1998) Role of cuticule degrading proteases in the virulence of Metarhizium spp. for the desert locust, Schistocerca gregaria. J.Nvertebr. Pathol 71:128-137

Ito ET, Varea-Pereira G, Miyagui MT, Pinotti MHP, Neves PMOJ (2007) Production of extracellular protease by a Brazilian strain of Beauveria bassiana reactivated on coffee berry borer, Hypothenemus hampei. Braz Arch Biol Technol 50:217-223

Jakovljević VD, Vrvić MM (2016) Potential of pure and mixed cultures of Cladosporium cladosporioides and Geotrichum candidum for application in bioremediation and detergent industry. Saudi I Biol Sci Article in Press. http://www.sciencedirect.com/science/article/pii/S1319562X1600022X. Accessed 13 Feb 2016.

Kucera M (1971) Toxins of the entomophagous fungus Beauveria bassiana. II. Effect of nitrogen sources on formation of the toxic protease in submerged culture. J Invertebr Pathol 17:211-215

Larsen MD, Kristiansen KR, Hansen TK (1998) Characterization of the proteolytic activity of starter cultures of Penicillium roqueforti for production of blue veined cheeses. Int J Food Microbiol 43(3):215-221

Mechakra A, Auberger B, Remeuf F, Lenoir J (1999) Optimisation d'un milieu de culture pour la production d'enzymes prote'olytiques acides par Penicillium camemberti. Sci Aliment 19:663-675

Murerwa P, Futi AP, Wanjiku KA, Maniania NK (2014) Effect of infection by Metarhizium anisopliae isolate ICIPE 51 on developmental stage, fecundity and intrinsic rate of increase of Rhopalosiphum padi and Metopolophium dirhodum. J Entomol Nematol 6(11):154-160

Samson RA, Evans HC, Latge JP (1988) Atlas of entomopathogenic fungi. Sproner-Verlag, Berlin, Heidelberge, New York, p 187

Sandhya C, Sumantha A, Szakacs AG, Pandey A (2005) Comparative evaluation of neutral protease production by Aspergillus oryzae in submerged and solidstate fermentation. Process Biochem 40:2689-2694

Saranya S, Ushakumari R, Jacob S, Babu Philip M (2010) Efficacy of different entomopathogenic fungi against cowpea aphid, Aphis craccivora (Koch). Journal of Biopesticides 3(1 Special Issue):138-142

Shahid AA, Rao AQ, Bakhsh A, Husnain T (2012) Entomopathogenic fungi as biological controllers: new insights into their virulence and pathogenicity. Arch Biol Sci 64(1):21-42 2012 Belgrade

Shahid AA, Sattar A, Chaudhry B, Riazuddin S (2003) Determination of protein virulence factors and pathogenicity of entomopathogenic fungi. Pak J Biochem Mol Biol 36:100-107

Shimizuy S, Tsuchitan I, Matusumoto T (1993) Production of an extracellular protease by Beauveria bassiana in the haemolymph of the silkworm, Bombyx mori. Lett Appl Microbiol 16:291-294

St. Leger RJ, Charnley AK, Cooper M (1986) Cuticle degrading enzymes of entomopathogenic fungi: mechanisms of interaction between pathogen enzymes and insect cuticle. J Invertebr Pathol 47:295-302

St. Leger RJ, Cooperand M, Charnley AK (1987) Production of cuticle degrading enzymes by the entomopathogen Metarhizium anisopliae during infection of cuticles from Calliphora vomitoria and Manduca sexta. J Gen Microbiol 133: 1371-1382

Vinayaga Moorthi P, Balasubramanian C, Selvarani S, Radha A (2015) Efficacy of sub lethal concentration of entomopathogenic fungi on the feeding and reproduction of Spodoptera litura. Springer Plus 4:681

Wells ML, McPherson RM, Ruberson JR, Herzog GA (2000) Effect of fungicide application on activity of Neozygites fresenii (Entomophthorales: Neozygi taceae) and cotton aphid (Homoptera: Aphididae) suppression. J Econ Entomol 93:1118-1126 